Інноватика у вихованні. Випуск 12. 2020.

УДК 378.015. 311: 373.3. 011. 3- 051

DOI: $\underline{10.35619 / \text { iiu.v1i12.309 }}$

Стельмашук Жанна

кандидат педагогічних наук, доцент кафедри теорії і методики виховання Рівненського державного гуманітарного університету,

м. Рівне, Україна

ORCID: 0000-0003-2368-4209,

e-mail:zhanna.stelmashuk@rshu.edu.ua

\title{
ЧИННИКИ РОЗВИТКУ ЕМОЦІЙНОГО ІНТЕЛЕКТУ У МАЙБУТНІХ УЧИТЕЛІВ ПОЧАТКОВОЇ ШКОЛИ
}

Анотація. У статті на основі здійсненого теоретичного аналізу розглянуто сутність поняття «емоційного інтелекту». Уточнено, що емоційний інтелект майбутніх учителів початкової школи являє собою сукупність здібностей, здатностей, знань, умінь і навичок, що дають змогу особистості розуміти власні емоції та емоції інших людей, управляти власними емоціями, створювати сприятливу емоційну атмосферу в процесі педагогічного спілкування.

Доведено неоднозначність поглядів учених щодо можливості розвитку емоційного інтелекту. 3'ясовано, що у сучасних психолого-педагогічних дослідженнях виділяють дві групи передумов розвитку емоційного інтелекту: біологічні (функціональна асиметрія мозку, властивості темпераменту та когнітивні здібності) та соціальні (умови родинної соціалізації, особистісні установки, власна активність особистості та іії релігійність).

Схарактеризовано біологічні передумови розвитку емоційного інтелекту майбутніх учителів початкової школи, його вікові закономірності розвитку в онтогенезі.

На основі застосування методів теоретичного аналізу, синтезу та узагальнення обгрунтовано педагогічні умови розвитку емоційного інтелекту у майбутніх учителів початкової школи (розуміння майбутніми учителями сутності емоційного інтелекту як важливої складової особистісної самореалізації та успішної професійної діяльності; створення сприятливого освітнього середовища в закладі освіти; впровадження в освітній процес закладу вищої освіти активних форм, методів та засобів його розвитку).

Ключові слова: емоційний інтелект, розвиток, учитель початкової школи, чинники, педагогічні умови.

Постановка проблеми. Актуальність проблеми розвитку емоційного інтелекту майбутнього учителя початкової школи обумовлена потребою підготовки педагога, який не лише має високий рівень знань, умінь та навичок 3 фаху, але й володіє здатністю до рефлексії як результату здатності розуміти власні емоції та емоції інших, уміє відчувати і враховувати емоційний стан особистості, встановлювати емоційний контакт та будувати ефективне педагогічне спілкування.

Окрім того, учитель початкової школи повинен бути емоційно стійким до стресових ситуацій, бути готовим не лише створювати здоровий психологічний 
мікроклімат у класі, а й розвивати у дітей молодшого шкільного віку емоційний інтелект як наскрізне уміння учня Нової української школи.

Наукові дослідження та практика роботи закладів освіти засвідчують, що саме розвинений емоційний інтелект особистості є однією з передумов успішної професійної діяльності.

Аналіз останніх досліджень 3 проблеми. Аналіз наукових праць зарубіжних та вітчизняних учених (Bar-On (1997); Гоулман (2011); К. Дерев'янко (2016), Д. Люсін (2004), Н. Коврига, Е. Носенко (2003), Mayer, J.D.\& Salovey (1993, 1995) та ін.) дав підстави дійти висновку, що загалом емоційний інтелект розглядається як здатність сприймати і розуміти власні емоції та емоції інших людей, керувати емоціями на основі інтелектуальних процесів, а також здатність до аналізу вчинків і причин власних емоційних станів та мотивів вчинків інших людей.

Водночас можемо констатувати неоднозначність позиції дослідників проблеми емоційного інтелекту щодо можливості його розвитку. Зокрема, Дж. Майєр та П. Селовей зауважували про малоймовірність підвищення рівня емоційного інтелекту, оскільки «це відносно стійка здібність» (Mayer, J.D.\& Salovey, 1995).

Натомість Д. Гоулман, один із розробників теорії емоційного інтелекту, $є$ прихильником іншої думки, зауважуючи, що «нервові шляхи мозку продовжують розвиватися аж до середини людського життя, а тому можливий і емоційний розвиток, який виявляється в усвідомленому регулюванні емоцій i полягає у розвитку таких здібностей, як самоконтроль, завзяття і наполегливість, а також уміння мотивувати свої дії» (Гоулман, 2011).

В окремих наукових розвідках 3 психології та педагогіки (Г.Кошонько (2013), І.Войціх (2016), Н.Деньга (2019) та ін.) зроблено спробу дослідити психолого-педагогічні умови розвитку емоційного інтелекту майбутніх психологів та педагогів.

Однак наразі існує потреба уточнення чинників формування емоційного інтелекту у майбутніх учителів початкової школи, що є метою цієї статті.

Виклад основного матеріалу дослідження. Уточнення чинників розвитку емоційного інтелекту у майбутніх учителів початкової школи потребує уточнення сутності та структурних елементів поняття «емоційний інтелект».

Слід зазначити, що грунтовне тлумачення поняття «емоційний інтелект» здійснено переважно у працях психологів. Зокрема, Д. Гоулман, американський журналіст і психолог, у праці «Emotional Inteligence» на матеріалах психологічних досліджень та опитувань довів, що успіх в житті залежить не стільки від логічного інтелекту IQ, як від здібностей керувати своїми емоціями. Відтак, емоційний інтелект він трактував як «особистісну властивість, здатність людини пояснювати власні емоції та емоції оточуючих 3 тим, щоб використовувати отриману інформацію для реалізації власних цілей» (Гоулман, 2011).

Інші американські психологи Дж. Майєр та П. Саловей під емоційнм інтелектом розуміють «здібність адекватно сприймати, оцінювати та виражати емоції; спроможність породжувати почуття, коли вони сприяють мисленню; спроможність розуміти емоції та знання, що стосуються емоцій, а також здібність регулювати емоції, щоб сприяти власному емоційному та інтелектуальному зростанню» (Mayer, J.D.\& Salovey , 1995). 
Російський психолог Д. Люсін пропонує трактувати емоційний інтелект як здатність до розуміння (людина може розпізнавати емоцію, тобто встановити сам факт наявності емоційного переживання у себе або в іншої людини; може ідентифікувати емоцію, тобто встановити, яку саме емоцію відчуває вона сама або інша людина, і знайти для неї словесний вираз; розуміє причини, що викликають цю емоцію, і наслідки, до яких вона приведе) і управління своїми та чужими емоціями (людина може контролювати інтенсивність емоцій, перш за все стримувати занадто сильні емоції; може контролювати зовнішнє вираження емоцій; може за необхідності довільно викликати ту або іншу емоцію) (Люсін, 2004). Автор виділив два види інтелекту: внутрішньоособистісний та міжособистісний емоційний інтелект.

Під емоційним інтелектом майбутніх учителів початкової школи будемо розуміти сукупність здібностей, здатностей, знань, умінь і навичок, що дають змогу особистості розуміти власні емоції та емоції інших людей, управляти власними емоціями й, аналізуючи ситуацію спілкування, створювати сприятливу емоційну атмосферу в процесі педагогічного спілкування.

Аналіз педагогічних та психологічних джерел 3 проблеми розвитку емоційного інтелекту особистості засвідчив інтерес науковців до проблеми визначення чинників, які мають вплив на розвиток емоційного інтелекту особистості.

Приміром, доктор педагогічних наук Л. Буркова (Буркова, 2010) пропонує відсоткове співвідношення факторів впливу на розвиток емоційного інтелекту людини: генотип батьків (40\%), виховання в сім'ї (10\%) та соціальне середовище $(50 \%) »$.

Грунтовний аналіз передумов розвитку емоційного інтелекту знаходимо у навчально-методичному посібнику С. Дерев'янко «Феноменологія емоційного інтелекту» (2016). Дослідниця виділила дві групи передумов: біологічні, що обумовлені генетично (функціональна асиметрія мозку, властивості темпераменту і когнітивні здібності), та соціальні (умови родинної соціалізації, особистісні установки, власна активність особистості та іiі релігійність) (Дерев'янко, 2016, С.145-146).

Існують біологічні передумови емоційного інтелекту: чим вищий рівень IQ у батьків, тим вищий показник розвитку емоційної сфери у дітей. 3 огляду на це, не можна не погодитися 3 думкою Д. Гоулмана, що визначає головним біологічним чинником розвитку емоційного інтелекту домінування правої nівкулі. Як відомо, права півкуля відповідає за творче мислення, цілісність сприйняття, уяву. Відповідно діти із домінуванням правої півкулі здатні краще розпізнавати емоції та адекватно реагувати на почуття інших людей.

С. Дерев'янко зауважує, що «такі властивості темпераменту як нейротизм, екстраверсія, сумлінність взаємопов'язані з емоційним інтелектом як рисою особистості. Емоційна стійкість сприяє розумінню власних емоцій, однак утруднює процес інтерпретації емоцій інших людей. Сумлінність впливає на продуктивність розуміння емоцій інших.... Екстраверсія пов'язана з розумінням емоцій інших та управління власними емоціями» (Дерев'янко, 2016, с.145).

У психології доведено, що кінестетики більш емпатійні, більш раціонально реагують на емоційні впливи інших людей, як аудіали.

У свою чергу соціальні чинники відіграють також значну роль у розвитку емоційного інтелекту особистості. У контексті нашого дослідження закономірний науковий інтерес викликають педагогічні чинники розвитку 
емоційного інтелекту, які вважаються основними у формуванні емоційно зрілої особистості з моменту входження у простір освітнього середовища.

Слід зазначити, що емоційний інтелект в онтогенезі має вікові закономірності розвитку. Зокрема, характерними проявами емоційного інтелекту у юнацькому віці $є$ відповідальність за власні емоційні переживання при загальній високій експресивності емоцій.

Здатність до розуміння емоцій як складова емоційного інтелекту у цьому віці характеризується зростанням значення рефлексії емоційних переживань та різноманітністю переживань почуттів, а здатність до інтуїтивного розуміння емоцій виявляється у чуйності та естетичній сприйнятливості. Здатність управляти емоціями характеризується все більшим контролем за вираженням негативних емоцій, посилення емоційної саморегуляції.

Відбуваються зміни і в здатності до управління емоціями інших людей: зростає здатність до навмисного вираження емоцій та почуттів, які використовуються для впливу на інших. Як зауважує С. Дерев'янко, особи юнацького віку намагаються проаналізувати і роз'яснити конфліктні, складні ситуації, при цьому орієнтуються на потреби і особистісні особливості інших (Дерев'янко, 2016, с.155).

Однак урахування лише розглянутих вище чинників не є достатнім для розвитку емоційного інтелекту майбутніх учителів початкової школи. Важливо забезпечити дотримання певних педагогічних умов.

Аналіз наукових джерел та практики роботи закладів освіти дає підстави констатувати, що здобувачам освіти цієї вікової категорії притаманне різноманіття емоційних реакцій та способів їх вираження.

Насамперед необхідно домогтися усвідомлення майбутніми учителями розуміння сутності емоційного інтелекту та важливості його як для особистісної самореалізації, так і для подальшої професійної діяльності. Значний потенціал для цього мають такі фахові дисципліни, як-от: педагогіка, вступ до спеціальності, теорія і методика виховання, педагогічна майстерність тощо.

Необхідною умовою розвитку емоційного інтелекту майбутніх учителів початкової школи є створення сприятливого освітнього середовища в ЗВО. Адже сприятливий психологічний мікроклімат, атмосфера творчості, співробітництва, підтримки та партнерства $є$ запорукою ефективності розвитку досліджуваного феномена. Емоції під час спілкування 3 колегами та педагогами здатні пробудити відкритість у переживаннях та почуттях. Прийняття i розуміння кожної особистості здобувача освіти, вияв довіри і поваги до неї, ненав'язлива допомога та підтримка, відкритість та готовність завжди прийти на допомогу сприяє розвитку емоційного інтелекту.

Розвиток емоційного інтелекту майбутніх учителів початкової школи може відбуватися в різних видах діяльності, зокрема, у процесі організованого навчання і виховання.

Тому ще однією умовою розвитку емоційного інтелекту здобувачів освіти $€$ впровадження в освітній процес закладу вищої освіти активних форм, методів та засобів його розвитку. Слід зауважити, що під час визначення рівня емоційного інтелекту особистості беруть до уваги показники його чотирьох ключових критеріїв: когнітивний (здатність до ідентифікації власних емоційних станів та емоційних станів інших людей, емоційна обізнаність), рефлексивний (здатність до рефлексії своїх вчинків і причин емоційних станів, здатність до аналізу мотивів вчинків інших людей), поведінковий (здатність контролювати свій 
емоційний стан, використовувати отриману емоційну інформацію під час спілкування з оточуючими, здатність обирати свій спосіб досягнення мети) та комунікативний (здатність до внутрішнього позитивного настрою, до емпатійного ставлення до оточуючих та прояву комунікабельності).

Отже, доцільним буде застосування як традиційних, так i активних інноваційних форм, методів та засобів його розвитку.

Варто наголосити на значному потенціалі системи тренінгових занять задля розвитку емоційного інтелекту майбутніх учителів початкової школи, що передбачає застосування міні-лекцій, дискусій, дебат, рефлексії, психогімнастики, арт-терапії, інтерактивних вправ, рольових ігор, case study, swot-аналіз тощо. Приміром, для розвитку внутрішньо особистісного емоційного інтелекту доречними будуть вправи «Відгадай емоцію», «Намалюй настрій», «Стежинка емоцій», мозковий штурм «Позитивні і негативні сторони емоцій» міні-дискусія «Навіщо учителю емоції», проективний малюнок «Світ емоцій», натомість для розвитку міжособистісного інтелекту - міні-лекція «Як керувати емоціями», вправа «Мої досягнення», «Вербалізація емоцій дитини» тощо.

Окрім того, розвитку емоційного інтелекту майбутніх учителів початкової школи сприятиме і залучення їх до різних видів поза аудиторної роботи, зокрема, соціальних проєктів, акцій, заходів тощо.

Висновки i перспективи подальших розвідок. Отже, врахування обгрунтованих вище чинників розвитку емоційного інтелекту майбутніх учителів початкової школи значною мірою сприятиме вирішенню означеної проблеми, однак не вичерпує усіх можливостей щодо розвитку досліджуваного феномену під час професійної підготовки майбутніх педагогів. Перспективи подальших наукових пошуків вбачаємо у дослідженні форм, методів та засобів розвитку емоційного інтелекту у майбутніх учителів початкової школи.

\section{СПИСОК ВИКОРИСТАНИХ ДЖЕРЕЛ}

Bar-On, R. (1997). The Bar-On Emotional Quotient Inventory: Technical Manual. Toronto : Multi-Health Systems, 1997. 216 p.

Гоулман, Д. (2011). Эмоциональный интеллект. Москва: АСТ: Астрель. $478 \mathrm{c}$.

Mayer, J. \& Salovey, P. (1995). Emotional intelligence and the construction and regulation of feelings. Applied and Preventive Psychology. V.4. P.197-208.

Дерев'янко, С. Феноменологія емоиійного інтелекту: навч.-метод. посіб. Чернігів: Поліграф. 312 с.

Носенко, Е та Коврига, Н. (2003). Емоційний інтелект: концептуалізація феномену, основні функціі. Київ: Вища школа. 126 с.

Кошонько, Г. (2013). Розвиток емоційного інтелекту студентів-психологів. Збірник наукових працьь Наџіональної академії Державної прикордонної служби Украӥни. Педагогічні та психологічні науки. 2013. №4. сс. 341-350.

Войціх, I. (2016). Педагогічні умови формування емоційної компетентності майбутніх психологів у процесі професійної підготовки. Вісник Національної академї Державної прикордонної служби України. Серія: Педагогіка, Вип. 4. URL: http://nbuv.gov.ua/UJRN/Vnadped_2016_4_6 [Дата останнього звернення 2 жовтня 2020 ]

Деньга, Н. (2019). Педагогічні умови розвитку емоційного інтелекту майбутніх учителів початкових класів. Педагогічна освіта: теорія і практика. № 2 (26). cc. 238-242. 
Люсин, Д. та Ушаков, Д. (2004). Современные представления об эмоииональном интеллекте. Соииальный интеллект: Теория, измерение, исследования. Москва: Ин-т психологии РАН, 2004. сс. 29-36.

Буркова, Л. (2010). Соціономічні професії: інноваційна підготовка фахівиів у вищих навчальних закладах: монографія. НАПН України, Київ. нац. ун-т ім. Т. Шевченка. Київ. : Інфосистем, 277 с.

\section{REFERENCES}

Bar-On, R. (1997). The Bar-On Emotional Quotient Inventory: Technical Manual. Toronto : Multi-Health Systems, 1997. 216 p. [in English]

Goulman. D. (2011). Emotsionalnyy intellekt. [Emotional intelligence ]. Moskva: AST: Astrel. 478 s. [in Russian]

Mayer, J. and Salovey, P. (1995). Emotional intelligence and the construction and regulation of feelings. Applied and Preventive Psychology. V.4. P.197-208. [in English]

Derevianko, S. Fenomenolohiia emotsiinoho intelektu [Phenomenology of Emotional Intelligence]: navch.-metod. posib. Chernihiv: Polihraf.312 s. [in Ukrainian]

Nosenko, E ta Kovryha, N. (2003). Emotsiinyi intelekt: kontseptualizatsiia fenomenu, osnovni funktsii. [Emotional Intelligence: conceptualisation of the phenomenon, the main functions]. Kyiv: Vyshcha shkola. $126 \mathrm{~s}$. [in Ukrainian]

Koshonko, H. (2013). Rozvytok emotsiinoho intelektu studentiv-psykholohiv [Development of emotional intelligence of students-psychologists]. V: Zbirnyk naukovykh prats Natsionalnoi akademii Derzhavnoi prykordonnoi sluzhby Ukrainy. Pedahohichni ta psykholohichni nauky. No4. ss. 341-350. [in Ukrainian]

Voitsikh, I. (2016). Pedahohichni umovy formuvannia emotsiinoi kompetentnosti maibutnikh psykholohiv u protsesi profesiinoi pidhotovky [Pedagogical conditions for the formation of emotional competence of future psychologists in the process of professional training]. Visnyk Natsionalnoi akademii Derzhavnoi prykordonnoi sluzhby Ukrainy. Seriia: Pedahohika, Vyp. 4. URL: http://nbuv.gov.ua/UJRN/Vnadped_2016_4_6 [Data ostannoho zvernennia 2 zhovtnia 2020 ] [in Ukrainian]

Denha, N. (2019). Pedahohichni umovy rozvytku emotsiinoho intelektu maibutnikh uchyteliv pochatkovykh klasiv [Pedagogical conditions for the development of emotional intelligence of future primary school teachers]. Pedahohichna osvita: teoriia i praktyka. No 2 (26). ss. 238-242. [in Ukrainian]

Lyusin. D. ta Ushakov. D. (2004). Sovremennyye predstavleniya ob emotsionalnom intellekte. Sotsialnyy intellekt: Teoriya. izmereniye. Issledovaniya [Modern concepts of emotional intelligence. Social Intelligence: Theory, Measurement, Research]. Moskva: In-t psikhologii RAN. 2004. ss. 29-36. [in Russian]

Burkova, L. (2010). Sotsionomichni profesii: innovatsiina pidhotovka fakhivtsiv u vyshchykh navchalnykh zakladakh [Socionomic professions: innovative training of specialists in higher educational institutions]: monohrafiia. NAPN Ukrainy, Kyiv. nats. un-t im. T. Shevchenka. Kyiv. : Infosystem, 277 s. [in Ukrainian] 
Інноватика у вихованні. Випуск 12. 2020.

\title{
FACTORS OF THE DEVELOPMENT OF FUTURE PRIMARY SCHOOL TEACHERS' EMOTIONAL INTELLIGENCE
}

\author{
Zhanna Stelmashuk \\ Candidate of Pedagogical Sciences, \\ Associate Professor at the Department of Theory \\ and Methods of Education, \\ Rivne State University for the Humanities \\ ORCID : 0000-0003-2368-4209, \\ Rivne, Ukraine \\ e-mail: zhanna.stelmashuk@rshu.edu.ua
}

\begin{abstract}
The essence of the concept of "emotional intelligence" on the basis of the theoretical analysis is considered in the article

It was clarified that the emotional intelligence of future primary school teachers is a set of abilities, knowledge, skills and abilities that allow a person to understand their own emotions and the emotions of others, manage their own emotions, create a favorable emotional atmosphere in pedagogical communication.

The ambiguity of scientists' views on the possibility of developing emotional intelligence has been proved.

It was found that in modern psychological and pedagogical research there are two groups of prerequisites for the development of emotional intelligence: biological (functional asymmetry of the brain, temperament and cognitive abilities) and social (family socialization, personal attitudes, personal activity and religiosity).

The biological preconditions for the development of emotional intelligence of future primary school teachers, its age patterns of development in ontogenesis were characterized.

Based on the application of methods of theoretical analysis, synthesis and generalization the pedagogical conditions for the development of emotional intelligence in future primary school teachers are substantiated (future teachers' understanding of the essence of emotional intelligence as an important component of personal self-realization and successful professional activity; creating a favorable educational environment in the educational institution; introduction of active forms, methods and means of its development into the educational process of a higher education institution).

The conclusion is made about the need to find active forms, methods and means of developing emotional intelligence in future primary school teachers.

Key words: Emotional Intelligence, development, personality, a future primary school teacher, factors, pedagogical conditions.
\end{abstract}

Стаття надійшла до редакиії 10. 10. 2020 р. 